\title{
Neoliberalismo sexual: o mito e a sedução da liberdade nas sociedades formalmente igualitárias
}

Sexual neoliberalism: the myth and seduction of freedom in formally egalitarian societies

Ismael Gonçalves Alves' (iD 0000-0003-3580-9101

'Universidade do Extremo Sul Catarinense, Programa de Pós-Graduação em Desenvolvimento Socioeconômico, Criciúma, Santa Catarina, Brasil 88806-000-ppgds@nesc.net

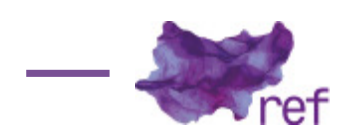

MIGUEL, Ana de.

Neoliberalismo sexual: el mito de la libre elección.

Madrid: Ediciones Cátedra/Universidad de Valencia, 2016.

Nas últimas décadas temos presenciado no mundo ocidental a proliferação de um conjunto sincrônico de discursos afirmando que as desigualdades e a falta de liberdade das mulheres seriam condições já superadas. Tal realidade teria sido alcançada pela ratificação de legislações que supostamente garantiriam em diversos âmbitos da vida pública, e também privada, a paridade social, econômica, política e cultural entre os sexos. Baseadas nesse axioma, as mulheres estariam aptas a adentrar sem restrições nos mundos do trabalho, a controlar livremente seus corpos e suas sexualidades, além de dividir de forma equânime com os homens as tarefas domésticas e de cuidados. Para os artífices de tais prédicas, as sociedades democráticas contemporâneas teriam chegado a tal nível de igualdade formal que o movimento feminista, como teoria e práxis, já não justificaria mais sua existência, tornando-se, assim, uma peça obsoleta e antiquária, digna apenas de um velho gabinete de curiosidades do século XIX.

Dessa forma, tocadas pelas luzes da liberdade neoliberal, as mulheres do século XXI seriam suficientemente autônomas para fazer suas escolhas e desbravar um mundo totalmente igualitário. De acordo com Nancy Fraser (2015), o discurso neoliberal que atualmente enreda nossas vidas ancora-se na premissa de que as relações sociais contemporâneas estão fundamentadas na livre escolha, nas trocas entre iguais e, sobretudo, nas conquistas meritocráticas, fechando os olhos para as desigualdades estruturantes que cuidadosamente foram questionadas por grupos subalternos. Nesse cenário de suposta autodeterminação, patriarcado e neoliberalismo se retroalimentam por meio de mecanismos em que a violência já não se exerce mais na forma legislações discriminatórias, mas é também fomentada por uma poderosa indústria cultural, que transforma tudo em mercadoria, inclusive os corpos e as sexualidades das mulheres.

Nesse contexto de discursos extremamente palatáveis e avessos às conquistas do feminismo, a filósofa espanhola Ana de Miguel, professora titular de Filosofia Moral e Política da Universidad Rey Juan Carlos, publica o livro intitulado Neoliberalismo sexual: el mito de la libre elección, distribuído pela editora Cátedra da Universidade de Valência. Ao longo de 351 páginas e ancorada no 
feminismo da igualdade, a autora sustenta a tese de que nas sociedades formalmente igualitárias e radicalmente democráticas da contemporaneidade a igualdade entre homens e mulheres não existe, sendo substituída por novas formas de dominação objetivas e simbólicas que operam na imposição das desigualdades. Assim, por meio de uma meticulosa investigação sobre o tempo presente, Ana de Miguel analisa argumentos que, amplamente divulgados junto à opinião pública, sustentam o que chama de mito da livre escolha e de patriarcado do consentimento. Difundido na Espanha pela filósofa Alicia Puleo, o patriarcado de consentimento é definido como uma nova roupagem para a violência do antigo patriarcado que, atualmente, impedido por leis positivas e antidiscriminatórias, incita a determinadas "condutas sexuais por meio de imagens atrativas e poderosos mitos vinculados em grande parte pelos meios de comunicação'" (Alicia PULEO, 1995, p. 31). Assim, afirma Ana de Miguel, mesmo com a existência de legislações igualitárias, o coletivo de mulheres não deixou de sofrer discriminações, violências e outras formas de opressão nas relações socioculturais. Aos feminismos caberia então colocar fim a argumentos que sustentam sua suposta obsolescência, desvelando os conteúdos patriarcais que estimulam discursos de ódio com a clara intenção de deturpar seu papel como agente transformador. Nas palavras da autora:

Efetivamente o feminismo é um humanismo, é a luta pelo reconhecimento das mulheres como sujeitos humanos e sujeitos de direito, é e sempre foi a luta por igualdade entre os sexos. E, no entanto, boa parte de sua má fama na imprensa é decorrente da associação que muitas pessoas fazem do feminismo com a luta pela supremacia feminina, [...] com a confusa ideia de que as feministas são contrárias a que as mulheres se apaixonem, sejam mães ou que sejam bonitas! $^{2}$ (Ana de MIGUEL, 2016, p. 27).

Com um tom extremamente político e dialogando com teóricas como Amelia Valcárcel, Alicia Puleo, Marcela Lagarde, Celia Amorós e Roxana Volio, apenas para citar alguns nomes, Ana de Miguel divide sua obra em onze capítulos distribuídos em três partes: "Onde estamos: desigualdade e consentimento"3; "De onde viemos e como o fizemos"4; e "Na direção em que queremos ir: homens e mulheres juntos" ${ }^{5}$, nos quais busca descontruir os argumentos neoliberais que anunciam a existência de uma sociedade igualitária. O caminho escolhido pela autora foi o de revelar como invisíveis mecanismos de violência patriarcal operam por meio da marca simbólica do sobrenome do pai, da compulsoriedade dos trabalhos de cuidados, da constante adequação dos corpos a padrões inatingíveis de beleza e do amor romântico, circunscrevendo as mulheres a existências cada vez mais subordinadas e menos livres. Por meio desses elementos, a autora demonstra como o feminismo continua insurgente ao denunciar que a mera inclusão de direitos de igualdade na democracia formal não modifica de maneira compulsória as relações objetivas, pois a "igualdade [formal] é um ponto de partida para um projeto de vida"6 mais igualitário e com potencia de transformação (MIGUEL, 2016, p. 87). Dos diversos elementos apontados pela autora como imprescindíveis para a existência do patriarcado de consentimento, dois recebem especial atenção: o amor romântico e a prostituição.

Sobre o amor romântico, tema clássico dos feminismos, a filósofa debruça-se sobre a ausência da reciprocidade nas relações afetivas entre homens e mulheres. De acordo com suas análises, para a grande maioria dos rapazes o amor não é um objetivo de vida, mas sim a busca incessante por desenvolver plenamente sua individualidade. Isso não significa que o amor ou a vida a dois, com família e filhos/as, não seja algo importante para os homens, mas eles disputam lugar dentro de um projeto global em que muitos outros elementos da vida são considerados, como, por exemplo, o sucesso no mundo laboral. Já as mulheres, bombardeadas desde muito jovens por romances, poemas, filmes e folhetins que lhes ensinam a amar e cuidar, o amor, ou, melhor dizendo, um certo tipo de amor romântico cria estratégias que buscam anulá-las como sujeitos, confinando-as nos papéis de mães e esposas de alguém. O amor patriarcal exige que a mulher carregue sozinha os pesos afetivo e emocional de uma relação em nome da suposta completude que só seu parceiro amoroso seria capaz de fornecer, ou seja, "um amor incondicional e eterno que reconhece uma total incompletude individual buscando a transcendência e a fusão com o outro até o ponto de se chegar à célebre frase: sem você não sou nada"7 (MIGUEL, 2016, p.

\footnotetext{
${ }^{1}[. .$.$] roles sexuales a través de imágenes atractivas y poderosos mitos vehiculados en gran parte por los medios de$ comunicación.

2 Efectivamente el feminismo es un humanismo, es la lucha por el reconocimiento de las mujeres como sujetos humanos y sujetos de derechos, es y ha sido siempre la lucha por la igualdad entre los sexos. Y, sin embargo, en buena parte de su mala prensa procede de que muchas asocian el feminismo con la lucha por la supremacía femenina, [...] con la confusa creencia de que las feministas están en contra de que las mujeres se enamoren, sean madres 0 iquieran verse guapas!

3 Dónde estamos: desigualdad y consentimiento.

${ }^{4}$ Dónde venimos y como lo hemos hecho

${ }^{5}$ Hacia dónde queremos ir: hombres y mujeres juntos

${ }^{6}$ La igualdad [formal] es un punto de partida para un proyecto de vida.

7 Un amor incondicional y eterno que reconoce una radical incompletitud individual y busca la transcendencia y la fusión con el otro hasta el punto del célebre 'sin ti no soy nada'.
} 
90), e por isso "as mulheres estariam dispostas a tudo para triunfar no amor ou por não reconhecer seu fracasso, inclusive suportar certas doses de violência"8 (MIGUEL, 2016, p. 90).

Sobre a prostituição, Ana de Miguel toma uma posição completamente abolicionista, argumentando que no contexto neoliberal a venda dos corpos, no mercado pornográfico e sexual, é aceita pela grande maioria da população que entende esse processo como uma troca entre iguais em que uma das partes escolhe comercializar seu corpo e a outra, com dinheiro suficiente, resolve comprá-lo. Transformando o sexo em mercadoria e extraindo dele valor, "o mercado se diversifica para que ninguém fique de fora, nem octogenários, nem feministas - com sua póspornografia - nem pessoas com deficiência. Para que nenhum pedaço de carne fique de fora do mercado"9 (MIGUEL, 2016, p. 123). Para a autora, no campo da prostituição não podemos esquecer que quem vende majoritariamente o sexo são as mulheres e que quem o compra são os homens, e é a partir dessa relação desigual que têm seus desejos sexuais satisfeitos, apoiados por uma ideologia que entende tal ação como normal, natural e desejável.

Criticando as posições pró-prostituição que defendem a ideia de que qualquer contrato efetuado entre adultos que haja sexo e consentimento deva ser respeitado e até mesmo legislado, Ana de Miguel lembra-nos que a grande maioria das mulheres prostituídas procede dos países mais pobres e desestruturados do mundo, onde são subalternizadas por uma sociedade injusta e patriarcal que lhes nega os conteúdos de cidadania e os direitos de escolha. Às pessoas que entendem a prostituição como uma relação laboral baseada na troca entre iguais, a autora adverte que o ato de ser prostituída é uma violência que não pode ser comparada ao trabalho, pois se ancora em relações de dominação brutais e sem qualquer tipo de mediação, nas quais corpos nus, sem nomes, humilhados e em fila ficam à disposição de homens com dinheiro para pagar por eles. Frente a esse argumento, Miguel recorda que uma sociedade que se quer justa e igualitária "não pode fomentar a relação de prostituição entre mulheres vulneráveis e todos os homens que querem acessar a seus corpos"10 sob o risco de desumanizá-las e torná-las meras mercadorias (MIGUEL, 2016, p. 162).

Por fim, Ana de Miguel, contrariando os discursos antifeministas, nos convoca a pensar a potência do feminismo nos processos socioculturais que impuseram substanciais mudanças nas estruturas e nas mentalidades ao longo da história. Por isso, a atualidade do movimento estaria na sua capacidade de transformar as desigualdades - que tocam de maneira especial as mulheres - em um problema público pertinente a todos aqueles comprometidos com a construção de um mundo mais justo. Por isso, nos incita a tomar um posicionamento duro diante das desigualdades, confrontando e reconhecendo as injustiças que ordinariamente assumem ares de normalidade, inevitabilidade e naturalidade. Assim, em um mundo neoliberal onde atrativos discursos sobre a suposta igualdade entre os sexos proliferam-se na mesma velocidade em que desqualificam a luta das mulheres, emerge a questão: como devemos encarar o feminismo? Respondo retomando as palavras da autora: "[é] melhor ver o feminismo como até agora foi visto: um movimento que foi e é decisivo para melhorar a vida das mulheres e com isso também de toda a comunidade humana"11 (MIGUEL, 2016, p. 345).

\section{Referências}

FRASER, Nancy. Fortunas del feminismo. Madrid: Traficante de Sueños, 2015.

PULEO, Alicia. "Patriarcado". In: AMORÓs, Celia. 10 palabras clave sobre mujer. Estella: Verbo Divino, 1995, p. 21-54

MIGUEL, Ana de. Neoliberalismo sexual: el mito de la libre elección. Madrid: Ediciones Cátedra/ Universidad de Valencia, 2016.

Ismael Gonçalves Alves (iga@unesc.net) é doutor em História, pela Universidade Federal do Paraná, UFPR (2014); mestre em História pela Universidade do Estado de Santa Catarina, UDESC (2009) e graduado em História (Bacharelado e Licenciatura) pela Universidade do Extremo Sul Catarinense, UNESC (2006). Na Universidade do Extremo Sul Catarinense é docente permanente do Programa de Pós-Graduação em Desenvolvimento Socioeconômico (PPGDS) junto à linha de pesquisa Desenvolvimento e Gestão Social e do Curso de História.

\footnotetext{
${ }^{8}$ Las mujeres estarían dispuestas a todo por triunfar en el amor o por no reconocer su fracaso, incluso a soportar situaciones de violencia.

${ }^{9}$ El mercado se diversifica para que nadie quede fuera, ni octogenarios, ni feministas - con su posporno - ni personas con diversidad funcional. Para que ningún trozo de cuerpo quede fuera del mercado.

${ }^{10}[\ldots]$ no puede fomentar a relación de prostitución entre las mujeres vulnerables y todos los hombres que quieren acceder sus cuerpos.

${ }^{11}$ Mejor ver el feminismo como lo que hasta ahora ha sido: un movimiento que ha sido y es decisivo para mejorar la vida de las mujeres y con ello de toda la comunidad humana.
} 


\section{COMO CITAR ESSE ARTIGO DE ACORDO COM AS NORMAS DA REVISTA}

ALVES, Ismael Gonçalves. "Neoliberalismo sexual: o mito e a sedução da liberdade nas sociedades formalmente igualitárias". Revista Estudos Feministas, Florianópolis, v. 27, n. 2, e59275, 2019.

\section{CONTRIBUIÇÃO DE AUTORIA}

Não se aplica

\section{FINANCIAMENTO}

Não se aplica

CONSENTIMENTO DE USO DE IMAGEM

Não se aplica

\section{APROVAÇÃO DE COMITÊ DE ÉTICA EM PESQUISA}

Não se aplica

\section{CONFLITO DE INTERESSES}

Não se aplica

\section{LICENÇA DE USO}

Este artigo está licenciado sob a Licença Creative Commons CC-BY Internacional. Com essa licença você pode compartilhar, adaptar, criar para qualquer fim, desde que atribua a autoria da obra.

\section{HISTÓRICO}

Recebido em: 19/09/2018

Aprovado em: 24/1 1/2018 